\title{
EFEK KEFIR TERHADAP GAMBARAN HISTOLOGIS DAN KADAR MALONDIALDEHIDE HEPAR MENCIT PUTIH (MUS MUSCULUS) JANTAN GALUR BALB C DENGAN PAPARAN FORMALIN
}

\author{
Erna Susanti dan Ni Made Dwi Aryantini \\ ${ }^{1}$ Akademi Farmasi Putra Indonesia Malang rna far@yahoo.co.id
}

\begin{abstract}
Kefir is a probiotic drink act as therapeutic agents in liver damage caused by exposure of formaldehyde. Therapeutic activities were estimate based on the content of kefir like antioxidants, lactic acid bacteria with yeasts, and essential amino acids. The purpose of this study was to prove the influence of kefir on the histological and levels of malondialdehyde (MDA) in liver of white mice (Mus musculus) male Balb C strain that exposure by formalin. The method used is experimental method, with three treatment groups, namely: (1) normal group, (2) the induction of formaline without kefir therapy group, (3) the induction of formaline with kefir therapy group. Histological of liver viewed by HE staining and MDA levels were measured by TBARS method. There are differences in the average number of significant cell damage induced by formalin group $(p=0030, p<0.05)$. There are significant differences in MDA levels induced by formalin group ( $p=0023, p<0.05)$. These results are based on the ability of vitamin C, E and carotene (antioxidant) against Reactive Oxygen Species (ROS) due to exposure of formaldehyde, thus preventing the MDA levels increasing. Lactic acid bacteria and yeasts can preclude the possibility of healthy cells to be attacked by ROS with increasing the body's immunity. Essential amino acids can repairing damaged cells by stimulating cell regeneration. It can be concluded that kefir with a dose of $10^{7} \mathrm{CFU} / \mathrm{ml}$ act as therapeutic agents in liver damage due to exposure to formaldehyde.
\end{abstract}

Keywords: Kefir, Exposure by Formaline, Liver Histological, Levels of Malondialdehyde.

\section{ABSTRAK}

Kefir merupakan minuman probiotik berperan sebagai agen terapi pada kerusakan hepar yang disebabkan paparan formalin. Aktivitas terapi tersebut diduga berdasarkan kandungan antioksidan, bakteri asam laktat dan khamir, serta asam amino essensial pada kefir. Tujuan penelitian ini adalah untuk membuktikan pengaruh dari kefir terhadap gambaran histologis dan kadar malondialdehide (MDA) pada hepar mencit putih (Mus musculus) jantan galur Balb C yang dipapar formalin. Metode yang digunakan pada penelitian ini yaitu metode eksperimental, dengan tiga kelompok perlakuan yaitu ; (1) kelompok normal, (2) kelompok induksi formalin tanpa terapi kefir, (3) kelompok induksi formalin dengan terapi kefir. Gambaran histologis hepar dilihat melalui pewarnaan HE dan kadar MDA diukur dengan metode TBARS. Hasil penelitian menunjukkan gambaran histologis hepar kelompok terapi kefir mengalami 
perbaikan dan hampir sama dengan gambaran histologis hepar kontrol (normal). Terdapat perbedaan rata- rata jumlah kerusakan sel yang signifikan dengan kelompok induksi formalin $(p=0.030, p<0.05)$. Kadar MDA hepar kelompok terapi kefir dapat diturunkan hingga kurang dari kadar MDA hepar kontrol (normal). Terdapat perbedaan kadar MDA yang signifikan dengan kelompok induksi formalin ( $p=0.023, p<0.05)$. Hasil ini didasarkan pada kemampuan vitamin $C, E$ dan karoten (antioksidan) dalam melawan Reactive Oxigen Species (ROS) akibat paparan formalin sehingga mencegah terjadinya peningkatan kadar MDA. Adanya bakteri asam laktat dan khamir dapat menghalangi kemungkinan sel-sel yang masih sehat untuk terserang oleh ROS melalui peningkatan imunitas tubuh. Kandungan asam amino esensial berfungsi dalam memperbaiki sel-sel yang rusak dengan cara merangsang produksi sel-sel baru (regenerasi sel). Dengan demikian dapat disimpulkan bahwa kefir dengan dosis $10^{7} \mathrm{CFU} / \mathrm{ml}$ berperan sebagai agen terapi pada kerusakan hepar akibat paparan formalin.

Kata Kunci : Kefir, Paparan Formalin, Gambaran Histologis Hepar, Kadar Malondialdehide.

\section{PENDAHULUAN}

Formaldehide adalah aldehide yang paling sederhana, dibuat secara besarbesaran melalui oksidasi methanol. Sekalipun berbentuk gas, formaldehyde tidak dapat disimpan dalam bentuk bebasnya, karena mudahnya senyawa ini berpolimerisasi. Formaldehyde sering dibuat dalam larutan $37 \%$ yang dinamakan formalin ${ }^{[1]}$. Formalin merupakan desinfektan yang sering digunakan sebagai bahan pengawet mayat (spesimen hayati) dengan konsentrasi $10 \%$.

Namun, dewasa ini terjadi penyalahgunaan formalin sebagai pengawet makanan dengan tujuan antara lain untuk memperpanjang usia makanan, memperbaiki penampilan luar makanan, dan melindungi makanan dari serangan jamur dan bakteri. Ternyata, mendapatkan formalin tidaklah sulit karena sejumlah toko kimia biasanya menyediakan dengan harga lima belas ribu rupiah perliter. Bahkan di sejumlah tempat, formalin dijual seharga tujuh ribu rupiah per liter yang umum dibeli oleh para nelayan ${ }^{[2]}$. Maka, selain harga yang terjangkau, ketersediaan formalin di pasaran yang mudah didapatkan juga menjadi pemicu penyimpangan penggunaannya sebagai pengawet makanan ini menjadi semakin luas. Kondisi ini tentunya berdampak bagi kesehatan masyarakat secara umum.

Hasil penelitian Softi (2002), menemukan dalam 60 sampel mie basah (boiled noodle) dari 32 pasar tradisional di Bandung positif mengandung formalin. Kandungan formalin sampel mie basah tersebut, berkisar antara 10,39 sampai $117,51 \mathrm{ppm}$. Sementara hasil penelitian Kurniawati (2004) menunukkan bahwa 19 sampel ikan basah perairan laut dan perairan umum dari 40 sampel ikan basah yang diambil dari empat pasar tradisional di Bandung positif mengandung formalin. Kandungan formalin dalam sampel ikan basah tersebut, berkisar antara 0,0010 ppm sampai dengan $0,9262 \mathrm{ppm}^{[3]}$.

Menurut The International for Occupational Safety Health (IOSH), kadar formaldehida yang berbahaya bagi kesehatan adalah lebih dari 20 ppm ${ }^{[4]}$. Bila diabsorpsi ke dalam aliran darah, formaldehida akan dimetabolisasi menjadi asam format kemudian akan dieksresikan melalui urine sebagai garam sodium atau dioksidasi lebih lanjut menjadi $\mathrm{CO}_{2}$ dan air. 
Proses detoksifikasi ini akan berjalan efektif jika konsentrasi formaldehida yang rendah dan pada konsentrasi yang tinggi menyebabkan metabolisme berjalan lambat yang dapat menimbulkan kerusakan jaringan [5].

Hepar merupakan organ pendetoksifikasi pertama terhadap segala sesuatu yang masuk ke dalam tubuh, baik melalui oral, inhalasi maupun rute pemberian lain. Terutamanya berhubungan langsung dengan saluran pencernaan, dimana duktus biliaris komunis dan duktus pankreatikus utama menyatu pada lengkung duodenum, menembus dinding duodenum dan memasuki lumen usus halus ${ }^{[6]}$. Kerja hepar yang berhubungan dengan toksikan, termasuk juga formalin, menyebabkan organ ini rentan terhadap pengaruh toksik formalin tersebut. Paparan formaldehid dalam hepar dapat menyebabkan menurunnya antioksidan di dalam tubuh, seperti superoksid dismutase (SOD) dan gluthation peroksidase (GSH.Px). Sebaliknya, meningkatkan produksi senyawa radikal bebas atau reactive oxigen species (ROS) yang apabila bereaksi dengan molekul dalam sel dan jaringan hepar, dapat menimbulkan stress oksidatif. Stress oksidatif adalah suatu kondisi tidak seimbang antara antioksidan yang ada dalam tubuh dengan produksi ROS, yang menyebabkan terjadinya peroksidasi lipid dan ditandai dengan meningkatnya produksi senyawa malondialdehide (MDA) dalam sel dan jaringan hepar. Apabila kondisi ini terus berlanjut, maka terjadi kerusakan dan kematian sel hepar ${ }^{[7]}$.

Dampak radikal bebas formaldehid yang menimbulkan stres oksidatif dapat dicegah dengan antioksidan. Salah satu sumber antioksidan adalah minuman probiotik yang merupakan minuman olahan susu dengan teknologi fermentasi sederhana, menggunakan bakteri asam laktat (LAB) yang kaya akan nutrisi ${ }^{[8]}$. Diketahui bahwa kefir adalah minuman probiotik yang memiliki kandungan antioksidan tinggi yaitu vitamin $\mathrm{C}$ dan $\mathrm{E}$ yang dapat berperan sebagai donor elektron dalam menghentikan sifat reaktif dari radikal bebas ${ }^{[9]}$. Secara tidak langsung, vitamin $\mathrm{C}$ dan $\mathrm{E}$ tersebut menginduksi enzim-enzim tertentu yang dapat meningkatan kadar antioksidan endogen seperti gluthation peroksidase (GSH.Px), superdiokside dismutase (SOD) dan katalase yang dapat menetralkan senyawa radikal bebas dan melarutkannya sehingga dapat dikeluarkan melalui sistem ekskresi tubuh ${ }^{[10]}$. Dinding bakteri asam laktat yang ada dalam kefir, mengandung senyawa peptidoglikan dan muramyl dipeptida (MDP) yang mampu mendorong terbentuknya sel-sel imun seperti sel limfosit $\mathrm{T}$, sel-sel $\mathrm{B}$ dan makrofag dalam meningkatkan ketahanan tubuh ${ }^{[4]}$. Adanya Bifidobacterium dalam kefir yang memacu pengeluaran IgA, membuat sistem pertahanan tubuh menjadi maksimal. Adanya asam amino esensial terutama triptopan, dapat membantu perbaikan sel (regenerasi sel) secara maksimal ${ }^{[11]}$.

Oleh karena itu, dibutuhkan sebuah langkah yang mampu memperjelas aktivitas kefir sebagai agen terapi pada hepar yang dipapar formalin. Langkah tersebut berupa desain penelitian dengan menggunakan mencit putih sebagai hewan coba, untuk menganalisis manifestasi perubahan kadar MDA dan gambaran histologis hepar antar perlakuan. Manifestasi tersebut tampak dari gambaran histologis organ hepar yang diamati dengan metode pewarnaan Hematoxylen - Eosin (HE) ${ }^{[12]}$. Sementara perubahan kadar malondialdehide (MDA) pada jaringan hepar tersebut dapat diukur 
dengan metode thiobarbituric acid reactive substance (TBARS) ${ }^{[13]}$.

\section{METODE PENELITIAN}

\section{Desain penelitian}

Penelitian ini menggunakan metode eksperimental menggunakan hewan uji mencit putih jantan galur Balb C. Variabel bebas dalam penelitian ini adalah kefir. Sedangkan variabel terikatnya adalah gambaran histologis dan kadar malondialdehide dari hepar mencit putih. Pemilihan sampel penelitian dilakukan secara Rancangan Acak Lengkap (RAL) dengan tiga perlakuan, yaitu (1) mencit putih dengan pemberian aquades (kelompok normal), (2) mencit putih dengan paparan formalin $25 \mathrm{ppm} 0,5 \mathrm{ml}$ p.o (kelompok induksi formalin), (3) mencit putih dengan paparan formalin $25 \mathrm{ppm} 0,5 \mathrm{ml}$ p.o yang diterapi kefir dosis $10^{7} \mathrm{CFU} / \mathrm{ml}$ 0,5 ml p.o (kelompok terapi kefir). Perlakuan dilaksanakan selama 14 hari. Penelitian ini telah mendapat persetujuan etik penelitian yang dikeluarkan oleh Akademi Farmasi Putra Indonesia Malang.

\section{Waktu dan Tempat Penelitian}

Penelitian dilakukan di Laboratorium Mikrobiologi dan Laboratorium Farmakologi Akademi Farmasi Putra Indonesia Malang, Laboratorium Ilmu Faal FK Universitas Brawijaya Malang, serta Laboratorium Biomedika FK Universitas Muhammadiyah Malang pada pertengahan bulan April hingga pertengahan Juli 2011.

Sampel yang digunakan sejumlah 15 ekor hewan uji. Karakteristik sampel yang digunakan antara lain; mencit putih (Mus musculus) galur Balb $C$ dengan jenis kelamin jantan, berusia 2-3 bulan, memiliki berat badan sebesar 30-35 g serta tidak terdapat cacat fisik.

\section{Pengujian Mutu Kefir}

Pengujian dilakukan dengan metode hitungan cawan. Bakteri kefir dibiakkan dalam media Man Rogessa Sharpe Agar (MRSA) yang merupakan media selektif untuk pertumbuhan bakteri asam laktat, kemudian diinkubasi selama 1 x 24 jam. Jumlah koloni bakteri dihitung berdasarkan Standar Plate Count (SPC).

\section{Perlakuan pada hewan uji}

Sebelum diberi perlakuan, mencit putih diadaptasikan selama 7 hari pada kondisi laboratorium. Selanjutnya, dilakukan penimbangan bobot badan dan dibagi kedalam 3 kelompok secara RAL. Pada minggu pertama dilakukan pemaparan formalin pada kelompok (2) dan (3), kemudian di minggu kedua dilakukan terapi kefir pada kelompok (3). Sementara untuk kelompok (1) hanya diberi aquadest selama 2 minggu tersebut. Mencit putih dibedah setelah 14 hari perlakuan, diambil organ heparnya untuk pembuatan preparat histologis dan pemeriksaan kadar MDA.

\section{Pembuatan Preparat Hepar}

Hepar direndam dalam larutan fiksatif yaitu formalin $10 \%$. Kemudian direndam lagi dalam etanol $70 \%$, dilanjutkan dengan perendaman dalam etanol $80 \%$ yang masing-masing perlakuan berlangsung selama 2 jam. Perendaman kembali dalam etanol $90 \%$, lalu etanol $95 \%$, dilanjutkan dalam etanol absolut yang masing-masing perendaman dilakukan selama 20 menit. Selanjutnya, hepar dicelupkan dalam parafin cair yang dituang dalam wadah. Setelah beberapa saat, parafin akan memadat dan hepar berada dalam blok parafin (embeding). Hasil embeding hepar dipotong dengan ketebalan irisan 5-10 mikrometer. Irisan 
tersebut diambil dengan kuas dan dimasukkan dalam air hangat untuk membuka lipatan yang mungkin terjadi pada preparat, direntangkan sempurna pada object glass. Potongan dikeringkan dan diletakkan di atas hot plate $\left(38-40^{\circ} \mathrm{C}\right)$. Preparat disimpan dalam inkubator pada suhu $38-40^{\circ} \mathrm{C}$ selama 24 jam ${ }^{[4]}$.

\section{Pengukuran Kadar MDA Hepar}

Sebanyak $10 \mathrm{mg}$ jaringan hati basah dihancurkan kemudian dihomogenasi dengan homogenizer. Tambahkan dengan 1 ml aquadest kemudian ditampung di ependorf. Selanjutnya, ditambahkan dengan TCA 100\% 100 ìl, NaThio 1\% 100 il, dan HCMN sebanyak 250 ìl. Panaskan pada suhu $100^{\circ} \mathrm{C}$ selama 20 menit. Sentrifuse dengan kecepatan $3500 \mathrm{rpm}$ selama 10 menit. Ambil supernatant kemudian tambahkan dengan aquades ad 3500 ìl. Kemudian, dibaca dengan spektrofotometer pada gelombang 532-534 nm. Sebagai standar digunakan 1,1,3,3tetramethoxypropane. Nilai TBARS dinyatakan dalam ng/mL MDA jaringan hati [14].

\section{Analisis Statistik}

Data hasil penghitungan jumlah kerusakan sel dan kadar MDA hepar pada masing-masing perlakuan dianalisis menggunakan OneWay- ANOVA dengan terlebih dahulu menguji distribusi normal dan homogenitas variannya. Selanjutnya, dilakukan uji Tukey untuk melihat kelompok perlakuan yang memberi perbedaan nyata. Analisis data dilakukan dengan komputerisasi menggunakan program SPSS for Windows versi 14.

\section{HASIL DAN PEMBAHASAN}

\section{Hasil penelitian}

Penghitungan jumlah bakteri dalam kefir dilakukan dengan menggunakan metode hitungan cawan. Jumlah koloni yang tumbuh pada cawan tempat bakteri kefir dibiakkan tersebut dihitung berdasarkan Standart Plate Count (SPC).

Pengamatan bobot hewan uji dilakukan dengan menimbang hewan uji setiap hari sebelum diberi perlakuan dan pakan. Hasil penimbangan kemudian dirata-rata untuk dilakukan perbandingan antar kelompok perlakuan.

Dari Tabel 2 tampak bahwa terjadi penurunan bobot hewan uji pada masa induksi formalin, baik terhadap kelompok perlakuan maupun kelompok kontrol. Sementara itu, terjadi peningkatan bobot hewan uji pada kelompok kontrol dan kelompok terapi kefir selama masa terapi.

Pengamatan makroskopis terhadap organ hepar hewan uji dilakukan segera setelah hewan uji dibedah. Kriteria pengamatan meliputi warna, tingkat kepucatan, serta ada tidaknya bintik-bintik putih sebagai indikasi perubahan histologis. Setiap organ hepar dari kelompok perlakuan dibandingkan dengan organ hepar dari kontrol.

Gambar 1 memperlihatkan efek pemberian formalin terhadap warna hepar mencit putih. Bila dibandingkan dengan kontrol, warna hepar dari kelompok induksi formalin adalah merah sangat pucat dan terdapat banyak bintik-bintik putih di permukaannya. Sementara, warna hepar dari kelompok terapi kefir yaitu merah agak pucat dengan sedikit bintik-bintik putih. Konsistensi hepar kontrol yaitu padat dan kenyal, sementara hepar yang terinduksi formalin agak keras. Tingkat kekenyalan hepar yang telah diberi terapi kefir lebih baik daripada hepar yang diinduksi formalin. 
Tabel 1. Hasil penghitungan jumlah bakteri dalam kefir

\begin{tabular}{ccccc}
\hline \multirow{2}{*}{ Cawan } & Kontrol & \multicolumn{4}{c}{ Pengenceran } \\
& & $10^{-4}$ & $10^{-3}$ & $10^{-6}$ \\
\hline T $1 \times 24$ jam & & & \\
\hline A & Tak ada koloni yang tumbuh & 340 & 302 & 290 \\
B & Tak ada koloni yang tumbuh & 304 & 306 & 276 \\
\hline
\end{tabular}

Tabel 2. Hasil pengamatan rata-rata bobot hewan uji (g/hari) masing-masing kelompok

\begin{tabular}{cccccccc}
\hline \multirow{8}{*}{$\begin{array}{c}\text { Hari } \\
\text { Klp }\end{array}$} & 1 & 2 & 3 & 4 & 5 & 6 & 7 \\
\cline { 2 - 8 } & \multicolumn{7}{c}{ Masa indulssi formalin } \\
\hline I & 30.8 & 28.3 & 27.5 & 30 & 28 & 27 & 27 \\
II & 33.3 & 31 & 34 & 33 & 33 & 32.5 & 32.5 \\
III & 39.2 & 39 & 40 & 39.1 & 36.3 & 36.6 & 35
\end{tabular}

Ket : Klp I = Kontrol (normal) ; klp II $=$ induksi formalin; $\mathrm{klp} \mathrm{III} \mathrm{=} \mathrm{terapi} \mathrm{kefir}$

\begin{tabular}{cccccccc}
\hline $\begin{array}{c}\text { Hari } \\
\text { Klp }\end{array}$ & 8 & 9 & 10 & 11 & 12 & 13 & 14 \\
\cline { 2 - 8 } & \multicolumn{7}{c}{ Masa terapi kefir } \\
\hline I & 29.5 & 30.25 & 30.5 & 30.5 & 30 & 32 & 32.5 \\
II & - & - & - & - & - & - & - \\
III & 31.6 & 31.6 & 38.6 & 39 & 40 & 40.6 & 39.2 \\
\hline
\end{tabular}

Ket : Klp I $=$ Kontrol (nomal) ; klp II $=$ indulsi formalin ; klp III = terapi kefir ; Minus $(-)=$ H.u telah dibedah

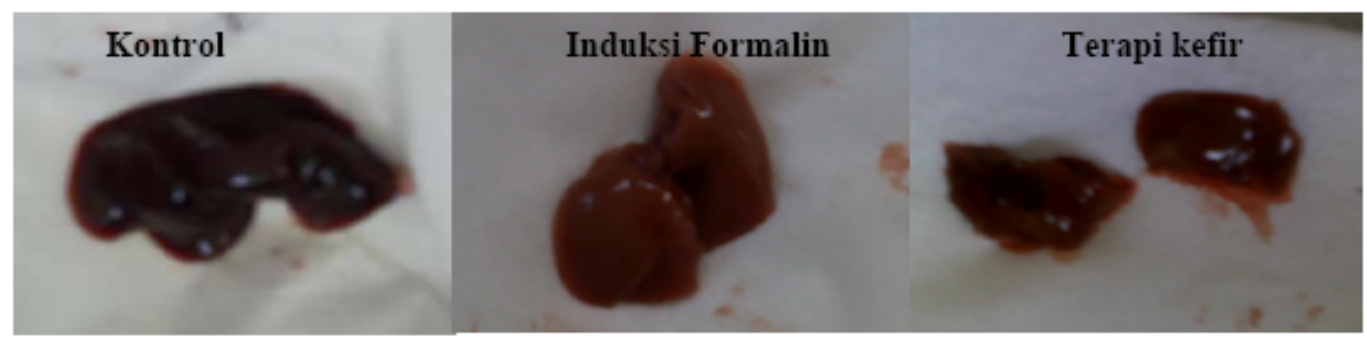

Gambar 1. Organ hati mencit pasca perlakuan 
Kerusakan sel yang terjadi pada hepar dihitung melalui pengamatan menggunakan mikroskop listrik dan dilihat pada perbesaran 100x dan 400x. Bentuk kerusakan sel yang dilihat meliputi nekrosis, degenerasi dan radang dari preparat hepar yang telah diwarnai dengan HematoxylenEosin

Hasil penghitungan kerusakan sel hepar mencit putih menunjukkan terjadinya peningkatan jumlah nekrosis, degenerasi maupun radang pada kelompok induksi formalin yang tidak diberi terapi kefir. Peningkatan jumlah kerusakan kelompok ini terlihat signifikan dengan rata-rata sebesar 98 daripada kerusakan pada kontrol yang memiliki rata-rata sebesar 17,8 . Sementara pada hewan uji yang telah diterapi dengan kefir menunjukkan penurunan jumlah kerusakan dari kelompok induksi formalin, yaitu dengan rata-rata kerusakan sebesar 52 buah. Berdasarkan hasil tersebut, diperlukan penelitian lebih lanjut tentang pengaruh waktu perlakuan terhadap jumlah kerusakan sel hepar yang terjadi.

Seperti terlihat pada gambar A, kerapatan antar sel dari masing-masing perlakuan berbeda. Dimana sel-sel hepar kontrol tampak rapat dengan bentuk inti sel yang bulat dan jernih. Sementara pada kelompok induksi formalin (gambar B) terlihat renggangnya ruang antar sel dan bentuk tersebut terdapat dalam jumlah yang banyak. Tampak pula sel-sel yang telah mengalami nekrosis dengan ciri inti sel mengkerut dan berwarna hitam, radang yang berwarna merah tua dan degenerasi sel yang membentuk ruang antar sel. Hal yang tak jauh beda tampak pada kelompok terapi kefir (gambar C) dimana masih terdapat sel radang, degenerasi dan nekrosis namun dalam jumlah yang lebih sedikit dibanding kelompok induksi formalin.
Berdasarkan analisis Anova terhadap jumlah kerusakan sel hepar, hasil $\mathrm{F}_{\text {hitung }}$ sebesar 10,439 yaitu lebih besar daripada $\mathrm{F}_{\text {tabel }}(2,12$ pada 0.05$)$ sebesar 3.890 sehingga Ho ditolak dan Ha diterima. Maka, ketiga kelompok menunjukkan adanya perbedaan jumlah kerusakan sel pada hepar mencit putih. Hasil pengujian berganda menggunakan uji Tukey didapatkan bahwa kelompok perlakuan yang berbeda secara bermakna $(\mathrm{p}<0,05)$ adalah kelompok kelompok kontrol/normal (I) dengan induksi formalin (II) dimana $p=0,002$. Serta antara kelompok induksi formalin (II) dengan terapi kefir (III) dimana $\mathrm{p}=0,030$.

Pengukuran kadar malondialdehide (MDA) dilakukan dengan metode TBARS (thiobarbituric acid reactive substance). Hasilnya adalah pigmen berwarna merah muda yang dapat diukur pada panjang gelombang 532-534 nm.

Tabel 3 menunjukkan hasil pengukuran kadar malondialdehide (MDA) hepar mencit putih yang diukur menggunakan metode asam tiobarbiturat pada spektrofotometer uv-vis dengan nilai $y=0,0156 x-0,0065$. Rata-rata kadar MDA dari kelompok induksi formalin sebesar 1,917 ng/mL tidak jauh berbeda dengan kadar MDA kontrol dengan rata-rata sebesar $1,776 \mathrm{ng} / \mathrm{mL}$. Sementara itu, terjadi penurunan kadar MDA yang signifikan pada kelompok mencit putih yang telah diterapi kefir dengan rata-rata sebesar 1,314 ng/mL.

Hasil analisis Anova menunjukkan nilai $F_{\text {hitung }}$ sebesar 5,099 yaitu lebih besar daripada $F_{\text {tabel }}(2,12$ pada 0.05$)$ sebesar 3,890 sehingga Ho ditolak dan Ha diterima. Maka, ketiga kelompok menunjukkan adanya perbedaan kadar MDA pada hepar mencit putih. Pengujian selanjutnya menggunakan uji Tukey menunjukkan terdapat kelompok perlakuan yang berbeda 
Tabel 3. Jumlah kerusakan sel hepar dari masing-masing kelompok

\begin{tabular}{cccc}
\hline $\begin{array}{c}\text { Mencit } \\
\text { No }\end{array}$ & Klp I & Klp II & Klp III \\
\hline 1 & 46 & 79 & 78 \\
2 & 3 & 82 & 33 \\
3 & 10 & 91 & 94 \\
4 & 8 & 91 & 26 \\
5 & 22 & 147 & 29 \\
Rata-rata & 17,8 & 98 & 52
\end{tabular}

Ket : Klp I = kontrol (normal) ; klp II = induksi formalin ; klp III = terapi kefir
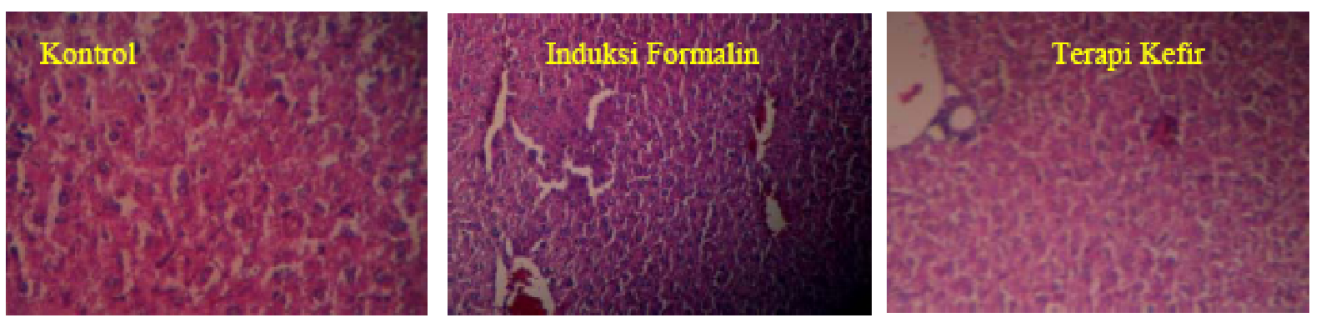

Ket : perbesaran $100 \mathrm{x}$

Gambar 2.Berikut ini memperlihatkan anatomi mikroskopik hepar mencit putih yang telah diwarnai dengan Hematoxylen-Eosin ( $\mathrm{HE}$ ) dari masing-masing kelompok. Kriteria perbandingan gambaran histologis antar kelompok perlakuan tersebut meliputi kerapatan antar sel, bentuk dan jumlah kerusakan yang terjadi.
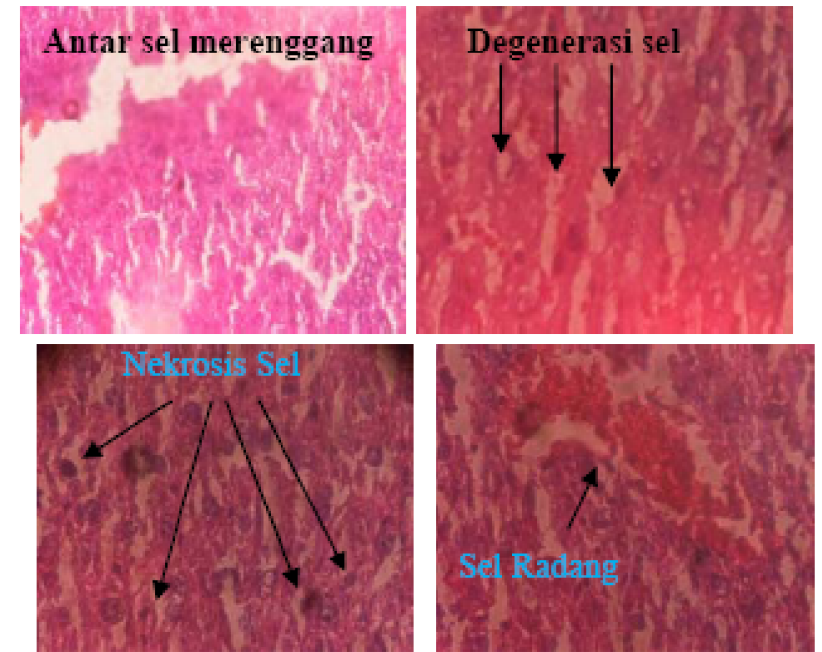

Ket : perbesaran $100 \mathrm{x}$

Gambar 3. Anatomi Mikroskopik Hepar Kelompok Induksi Formalin

Ket : perbesaran $400 \mathrm{x}$
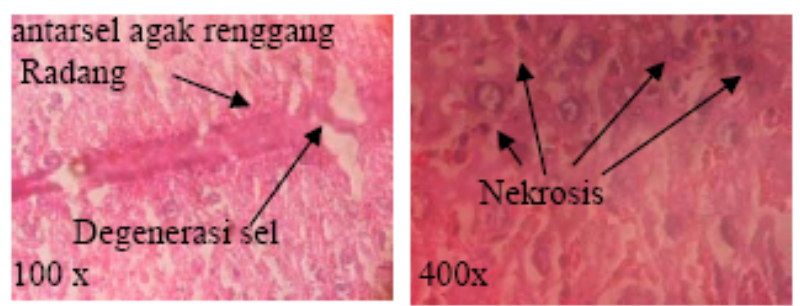

Gambar 4. Anatomi Mikroskopik Hepar Kelompok. Terapi Kefir 
secara bermakna $(\mathrm{p}<0,05)$ yaitu antara antara kelompok perlakuan induksi formalin (II) dengan terapi kefir (III), dimana $\mathrm{p}=$ 0,023 .

\section{Pembahasan}

Penelitian ini bertujuan untuk mengetahui hasil terapi kefir terhadap mencit putih yang dipapar formalin berdasarkan gambaran histologis dan kadar malondialdehid (MDA) hepar. Kefir merupakan bahan uji yang penting dalam penelitian menyangkut dengan manfaat yang ingin diperoleh dari susu fermentasi ini. Diketahui bahwa kefir mengandung bakteri Lactobacillus yang merupakan salah satu bakteri probiotik. WHO telah menetapkan standar jumlah bakteri probiotik dalam susu fermentasi yaitu sebesar $10^{6}-10^{8} \mathrm{CFU} / \mathrm{ml}^{[8]}$. Oleh karena itu, dilakukan pengujian kualitas kefir terkait dengan jumlah bakteri asam laktat yang terkandung di dalamnya. Pengujian dilakukan dengan metode hitungan cawan dan penghitungan berdasarkan Standar Plate Count (SPC). Bakteri kefir dibiakkan dalam media Man Rogessa Sharpe Agar (MRSA) yang merupakan media selektif untuk pertumbuhan bakteri asam laktat ${ }^{[15]}$. Hasil penghitungan terhadap jumlah bakteri asam laktat yang tumbuh dalam media selama 1 x 24 jam tersebut sebesar $2.83 \times 10^{8} \mathrm{CFU} /$ $\mathrm{ml}$. Hal ini berarti kefir yang digunakan dalam pengujian telah memenuhi standar yang ditetapkan WHO.

Berdasarkan pertimbangan dari hasil penelitian terdahulu, bahwa pada dosis minuman probiotik (yoghurt) sebesar $10^{6}$ CFU/ml telah mampu memperbaiki gambaran histologis organ usus halus ${ }^{[4]}$. Maka, peneliti mencoba keefektifan dosis yang lebih tinggi untuk kefir yaitu sebesar $10^{7} \mathrm{CFU} / \mathrm{ml}$ sebagai dosis terapi terhadap hepar mencit putih yang dipapar formalin ini. Sehingga dilakukan pengenceran dari dosis kefir yang telah didapatkan yaitu $10^{8}$ $\mathrm{CFU} / \mathrm{ml}$ menjadi $10^{7} \mathrm{CFU} / \mathrm{ml}$. Pengenceran dilakukan dengan cara memipet $1 \mathrm{ml}$ kefir menggunakan pipet ukur lalu dimasukkan dalam $9 \mathrm{ml}$ susu UHT, maka didapatkan 10 $\mathrm{ml}$ kefir dengan dosis $10^{7} \mathrm{CFU} / \mathrm{ml}$. Penggunaan susu UHT dimaksudkan untuk mencegah kontaminasi dari bakteri lain yang dapat mempengaruhi jumlah bakteri probiotik dalam kefir ini. Kefir dengan dosis sebesar $10^{7} \mathrm{CFU} / \mathrm{ml}$ ini disimpan dalam lemari es untuk menjaga kualitasnya selama masa penggunaan.

Pada perlakuan penelitian, prosedur kerja terhadap mencit putih yang dibagi dalam tiga kelompok telah dilakukan sesuai jadwal. Pada minggu pertama, kelompok perlakuan dipapar formalin dengan dosis 25 ppm sebanyak 0,5 ml. Ambang batas keamanan formalin yang ditetapkan IOSH (International Occupational Safety Health) adalah $20 \mathrm{ppm}^{[4]}$. Maka, dari dosis formalin sebesar 25 ppm diharapkan dapat menimbulkan tanda-tanda patologis organ hepar dalam rentang waktu induksi selama satu minggu. Mengingat bahwa formalin merupakan karsinogenik, maka volume pemberian perlu disesuaikan dengan dosis agar tidak melebihi ambang batas letal dose $\left(\mathrm{LD}_{50}\right)$ yang dapat menyebabkan kematian hewan uji ${ }^{[3]}$. Berdasarkan hasil perhitungan, didapatkan bahwa volume pemberian sebesar $0,5 \mathrm{ml}$ tidak melebihi ambang batas $\mathrm{LD}_{50}$

Selama masa induksi formalin, tingkat keaktifan hewan uji diamati sebagai parameter pendukung penelitian. Hal ini dimaksudkan untuk mengetahui sejauh mana formalin yang dipaparkan pada mencit putih mempengaruhi aktivitas, kepekaan terhadap rangsang dan kondisi fisiologisnya. Hasil 


\begin{tabular}{l} 
Tabel 3. Kadar malondialdehid hepar (dalam ng/mL) masing-masing kelompok \\
\cline { 2 - 4 } \\
\begin{tabular}{ccccc} 
Mencit & \multicolumn{3}{c}{ Perlakuan } \\
No & $\begin{array}{c}\text { Kelompok } \\
\text { I }\end{array}$ & $\begin{array}{c}\text { Kelompok } \\
\text { II }\end{array}$ & $\begin{array}{c}\text { Kelompok } \\
\text { III }\end{array}$ \\
\hline 1 & 2,788 & 1,827 & 1,635 \\
2 & 1,442 & 2,147 & 1,250 \\
3 & 1,378 & 1,699 & 1,122 \\
4 & 1,635 & 2,147 & 1,378 \\
5 & 1,635 & 1,763 & 1,186 \\
Rata-rata & 1,776 & 1,917 & 1,314 \\
\hline
\end{tabular}
\end{tabular}

Ket : Klp I = kontrol (normal) ; klp II = induksi formalin ; klp III = terapi kefir

pengamatan menunjukkan bahwa mencit putih mengalami penurunan kondisi fisiologis dan kepekaan terhadap rangsang, walaupun secara umum, hewan uji ini tetap terlihat aktif. Paparan formalin yang terusmenerus selama satu minggu menyebabkan munculnya tanda-tanda patologis dalam tubuhnya. Hal tersebut dapat dilihat secara fisik seperti lidah membiru, warna mata memucat, dan bulu yang mulai rontok.

Selain itu, paparan formalin juga mengganggu sistem pencernaan dan ekskresi dari mencit putih. Peneliti mengamati bahwa hasil ekskresi berupa feses memiliki konsistensi yang lembek dengan jumlah banyak serta warna yang kehitaman. Sementara pengeluaran urine dari mencit putih ini sedikit, namun berwarna kuning pekat dengan bau menyengat. Hal ini tampak dari kondisi sekam yang kering dan pengeluaran urine yang dilakukan oleh mencit putih saat akan disuntik. Penurunan kepekaan rangsang tampak pada saat pemberian makan, dimana mencit putih tidak segera menyantap makanan yang diberikan. Hal ini terjadi pada hari ke-5 masa induksi formalin dan masih berlangsung hingga awal masa terapi. Penurunan nafsu makan ini mengakibatkan perawakan hewan uji terlihat kurus, diperjelas pula dari hasil penimbangan rata-rata bobot badan mencit putih yang mengalami penurunan secara signifikan pada semua kelompok perlakuan.

Hal yang berbeda terjadi pada pengamatan yang dilakukan selama masa terapi kefir di minggu kedua. Kefir diberikan dalam dosis sebesar $10^{7} \mathrm{CFU} / \mathrm{ml}$ sebanyak $0,5 \mathrm{ml}$. Diperkirakan dosis sebesar $10^{7} \mathrm{CFU} /$ $\mathrm{ml}$ tersebut dapat mempercepat perbaikan kondisi dari hewan uji yang sebelumnya telah dipapar formalin. Pemberian sebanyak 0,5 ml dimaksudkan supaya sebanding dengan volume pemberian formalin, sehingga tidak terjadi keberagaman volume pemberian pada hewan uji yang memiliki bobot rata-rata sama ini.

Hasil pengamatan terhadap tingkat keaktifan maupun bobot badan mencit putih selama masa terapi menunjukkan adanya perbaikan. Peningkatan kondisi umum meliputi pengeluaran feses dan urine yang kembali normal. Konsistensi feses menjadi lebih padat dan berwarna kecoklatan. Sementara urine berwarna kuning jernih dan tidak lagi berbau menyengat. Maka, dengan pemberian kefir telah terjadi perbaikan terhadap sistem pencernaan maupun ekskresi dari hewan uji. Sistem pencernaan yang baik berdampak pada peningkatan nafsu makan, sehingga perawakan hewan uji 
menjadi lebih gemuk. Hasil penimbangan terhadap rata-rata bobot badan pun memberikan hasil yang memuaskan, dimana penambahan berat badan mencit putih ini menunjukkan hasil yang signifikan.

Perubahan lain yang tampak yaitu bulu yang kembali tumbuh sehingga tampak memutih dan perawakan yang mulai menggemuk. Diperkirakan, peningkatan imunitas terjadi selama masa terapi kefir, sehingga tanda-tanda patologis yang sebelumnya muncul mulai kembali normal. Hal ini sesuai dengan peranan dari bakteri asam laktat dan bifidobacteria yang terkandung dalam kefir, yaitu meningkatkan daya tahan tubuh (imunitas). Peningkatan imunitas terjadi karena dinding sel bakteri asam laktat mengandung muramyl dipeptida dan peptidoglikan yang memicu sel $\mathrm{T}$ dan sel B limfosit untuk memproduksi antibody [10]. Sehingga, faktor-faktor yang menyebabkan penurunan kondisi fisiologisnya dapat dicegah.

Berdasarkan penelitian Uun Kunaepah pada tahun 2008, menyebutkan bahwa khamir yang terkandung dalam kefir tak hanya berfungsi sebagai komponen pembentuk cita rasa, melainkan juga menghasilkan senyawa antibakteri yang disebut bakteriosin ${ }^{[16]}$. Luka-luka pada tubuh mencit putih akibat gesekan terhadap kawat kandang dapat cepat mengering, diduga akibat aktivitas antibiotik bakteriosin. Adanya antibiotik tersebut mencegah terjadinya infeksi pada luka, sehingga luka tak lagi tampak bernanah dan dapat sembuh.

Pengaruh induksi formalin maupun terapi kefir terhadap hepar hewan uji dilihat secara nyata melalui pengamatan makroskopis dan mikroskopis, serta pengukuran kadar malondialdehide (MDA) dari organ hepar mencit putih tersebut. Oleh karena itu, peneliti mengamati kondisi makroskopis, gambaran mikroskopis dan hasil pengukuran kadar MDA hepar antar kelompok perlakuan, yang dibandingkan dengan kelompok kontrol sebagai parameter hepar normal.

Hasil pengamatan terhadap kondisi makroskopis hepar dari kontrol (normal), kelompok induksi formalin maupun kelompok terapi kefir menunjukkan adanya perbedaan. Hal tersebut dinilai dari beberapa kriteria meliputi : warna, tingkat kepucatan, konsistensi serta ada tidaknya bintik-bintik putih sebagai indikasi histopatologis. Perubahan warna dan munculnya bintik-bintik putih terjadi pada hepar mencit kelompok induksi formalin dan terapi kefir. Warna hepar dari kedua kelompok ini sama-sama lebih pucat daripada warna hepar kontrol (normal) yang berwarna merah segar. Adanya bintik-bintik putih tersebut mengindikasikan bahwa telah terbentuk rongga-rongga pada permukaan hepar karena lisisnya sel akibat paparan formalin ${ }^{[17]}$. Bintik-bintik putih tersebut masih tetap ada pada hepar mencit kelompok terapi, namun dalam jumlah yang lebih sedikit dan ukuran yang lebih kecil, dibanding pada hepar kelompok induksi formalin.

Konsistensi hepar kontrol (normal) tampak padat dan kenyal, sementara hepar yang terinduksi formalin agak keras. Mengerasnya jaringan pada organ hepar ini akibat pengaruh formalin yang bersifat sebagai pengawet dengan cara merapatkan rangkaian protein pada jaringan ${ }^{[5]}$. Sementara, tingkat kekenyalan hepar yang telah diberi terapi kefir lebih baik daripada hepar yang diinduksi formalin.

Gambaran mikroskopis hepar yang ditunjukkan antar kelompok perlakuan, menunjukkan hasil yang sebanding dengan 
kondisi mikroskopis hepar mencit putih kontrol, yang diinduksi formalin maupun yang mendapat terapi kefir. Dilihat dari tingkat kerapatan selnya, sel-sel hepar kontrol (normal) tampak rapat dengan bentuk inti sel yang bulat dan jernih. Sementara pada kelompok induksi formalin terlihat renggangnya ruang antar sel dan bentuk tersebut terdapat dalam jumlah yang banyak. Tampak pula sel-sel yang telah mengalami nekrosis dengan ciri inti sel mengkerut dan berwarna hitam, radang yang berwarna merah tua dan degenerasi sel yang membentuk ruang antar sel ${ }^{[12]}$. Hal tersebut menunjukkan bahwa paparan formalin sebesar $25 \mathrm{ppm}$ dapat menyebabkan kerusakan sel hepar. Hal yang tak jauh beda tampak pada kelompok terapi kefir dimana masih terdapat sel radang, degenerasi dan nekrosis namun dalam jumlah yang lebih sedikit dibanding kelompok induksi formalin. Berkurangnya jumlah kerusakan pada kelompok terapi kefir diduga karena kandungan asam amino esensial dalam kefir yang berperan dalam memperbaiki sel-sel yang rusak dengan cara merangsang pembentukan sel-sel yang baru (regenerasi sel) ${ }^{[11]}$. Adanya suplementasi kefir dengan dosis $10^{7} \mathrm{CFU} / \mathrm{ml}$ ini memberikan perubahan yang lebih baik terhadap gambaran histologis hepar mencit putih.

Parameter pengukuran lain dalam penelitian ini adalah kadar malondialdehide (MDA) pada hepar mencit putih. Paparan formaldehid dalam hepar dapat menyebabkan menurunnya antioksidan di dalam tubuh, seperti superoksid dismutase (SOD) dan gluthation peroksidase (GSH.Px). Sebaliknya, meningkatkan produksi senyawa radikal bebas atau reactive oxigen species (ROS) yang apabila bereaksi dengan molekul dalam sel dan jaringan hepar, dapat menimbulkan stress oksidatif ${ }^{[10]}$. Stress oksidatif adalah suatu kondisi tidak seimbang antara antioksidan yang ada dalam tubuh dengan produksi ROS, yang menyebabkan terjadinya peroksidasi lipid dan ditandai dengan meningkatnya produksi senyawa malondialdehide (MDA) dalam sel dan jaringan hepar ${ }^{[7]}$. Oleh karena itu, pengukuran kadar Malondialdehide (MDA) dilakukan untuk mengetahui sejauh mana efektifitas terapi kefir dalam menghentikan terjadinya peroksidasi lipid akibat paparan formalin.

Hasil pengukuran terhadap rata-rata kadar MDA hepar mencit putih kelompok perlakuan dibandingkan dengan kontrol, telah menunjukkan perbedaan yang signifikan. Paparan formalin terbukti meningkatkan produksi malondialdehide sebagai hasil peroksidasi lipid yang terjadi pada organ hepar. Sementara itu, terjadi penurunan kadar MDA yang signifikan pada kelompok mencit putih yang telah diterapi kefir. Hasil tersebut menunjukkan bahwa pemberian kefir mampu menurunkan kadar malondialdehide (MDA) pada organ hepar mencit putih. Kefir yang kaya antioksidan (vitamin C, E dan karoten) berperan sebagai donor elektron dalam menghentikan sifat reaktif dari radikal bebas ${ }^{[11]}$. Secara tidak langsung, vitamin $\mathrm{C}$ dan $\mathrm{E}$ tersebut menginduksi enzim-enzim tertentu yang dapat meningkatan kadar antioksidan endogen seperti gluthation peroksidase (GSH.Px), superdiokside dismutase (SOD) dan katalase yang dapat menetralkan senyawa radikal bebas dan melarutkannya sehingga dapat dikeluarkan melalui sistem ekskresi tubuh [7]. Maka, kadar malondialdehide pun dapat diturunkan. 
Hasil penelitian menunjukkan pengaruh suplementasi kefir yang signifikan. Terlihat pada gambaran histologis hepar mencit putih kelompok terapi kefir yang mengalami perbaikan dan hampir menyerupai gambaran histologis hepar kontrol (normal). Selain itu, kadar MDA hepar kelompok terapi kefir dapat diturunkan hingga kurang dari kadar MDA hepar kontrol (normal). Diperkirakan terapi yang dilakukan oleh kefir melalui tiga mekanisme kerja. Pertama, kandungan antioksidan dalam kefir berupa vitamin $\mathrm{C}$, $\mathrm{E}$ dan karoten berperan dalam melawan radikal bebas yang meningkat akibat paparan formalin, sehingga dapat memperkecil terjadinya toksisitas pada hepar. Kedua, adanya Lactic Acid Bakteria (LAB) dan khamir yang menghalangi kemungkinan sel-sel yang masih sehat untuk terserang oleh radikal bebas melalui kemampuannya dalam meningkatkan imunitas tubuh. Ketiga, kefir mengandung asam amino esensial yang berfungsi dalam memperbaiki sel-sel yang rusak dengan cara merangsang produksi sel-sel baru (regenerasi sel).

Berdasarkan bahasan di atas, maka kefir sebagai minuman fermentasi dari susu sapi dengan Lactic Acid Bakteria (LAB) dan khamir ternyata mampu berperan sebagai agen terapi pada hepar yang dipapar formalin.

\section{PENUTUP}

\section{Kesimpulan}

Berdasarkan hasil penelitian ini dapat disimpulkan :

1. Pemberian kefir dapat memperbaiki gambaran histologis hepar mencit putih (Mus muscullus) jantan galur Balb C yang dipapar formalin hingga menyerupai gambaran histologis hepar normal.

2. Pemberian kefir dapat menurunkan kadar malondialdehide (MDA) dalam hepar mencit putih (Mus muscullus) jantan galur Balb $C$ yang dipapar formalin hingga menyerupai kadar malondialdehide (MDA) hepar normal.

3. Terdapat perbedaan gambaran histologis dan kadar malondialdehide (MDA) antara hepar mencit putih (Mus muscullus) jantan galur Balb $C$ yang normal, yang terpapar formalin, dan yang mendapat terapi kefir.

\section{Saran}

Berdasarkan hasil penelitian yang telah diperoleh, maka dapat disarankan sebagai berikut :

1. Masyarakat harus lebih berhati-hati dalam pemilihan bahan pangan dan makanan yang dikonsumsinya terkait dengan masih banyaknya penggunaan formalin sebagai pengawet makanan, yang dapat memberi dampak buruk bagi kesehatan.

2. Perlu pengawasan yang lebih ditingkatkan oleh BPOM atau Direktorat Perlindungan Konsumen terhadap bahan pangan yang menggunakan bahan kimia berbahaya yang beredar.

3. Perlu dilakukan penelitian lebih lanjut untuk menambah informasi dan menguatkan hasil penelitian dalam KTI ini seperti pengaruh waktu perlakuan terhadap jumlah kerusakan sel serta pengukuran kadar antioksidan endogen, baik Superdiokside Dismutase (SOD) maupun Gluthation Peroksidase (GSH.Px) dari hasil terapi kefir terhadap hepar yang dipapar formalin. 


\section{DAFTAR PUSTAKA}

Antara, I Dewa Made Dwi Indra. 2009. Identifikasi Formaldehid Hasil Depolimerisasi Melamin Dalam Peralatan Makan Rumah Tangga Yang Mendapat Perlakuan Pemanasan. Karya Tulis Ilmiah. Akademi Analis Farmasi Dan Makanan Putra Indonesia Malang.

Bahar, Burhan. 2008. Kefir Minuman Susu Fermentasi dengan Segudang Khasiat untuk Kesehatan. Jakarta : PT Gramedia Pustaka Utama.

Cahyadi M.Si, Dr. Ir. Wisnu. 2006. Analisis dan Aspek Kesehatan Bahan Tambahan Pangan. Jakarta : Sinar Grafika Offset.

Chanif Mahdi, Aulianiam, dkk. 2008. Yogurt Sebagai Detoksikan yang Efektif Terhadap Toksisitas Formalin yang Terpapar dalam Makanan. Jurnal Protein. Universitas Brawijaya Malang.

Divisi Fisiologi Molekuler Laboratorium Ilmu Faal. Prosedur analisa SOD dan MDA. Malang : Universitas Brawijaya.

Eroschenko,P.V. 2003. Atlas Histologi di Fiore dengan Korelasi Fungsional. Terjemahan Jan Tambayong : Edisi 9. Jakarta : ECG.

Hart, Suminar. Kimia Organik Edisi Keenam. Jakarta : Erlangga.

Jawi, I Made, Dewa Ngurah Suprapta, dkk. 2008. Ubi Jalar Ungu Menurunkan Kadar MDA dalam Darah dan Hati Mencit setelah Aktivitas Fisik Maksimal. Jurnal Veteriner. Universitas Udayana Denpasar.

Kunaepah, Uun. 2008. Pengaruh Lama Fermentasi dan Konsentrasi Glukosa Terhadap Aktivitas Antibakteri, Polifenol Total dan Mutu Kimia Kefir
Susu Kacang Merah. Tesis. Universitas Diponegoro Semarang.

Oeij, Anindita Andhika, wahyuni Lukita atmadja, Sadiah Achmad, aming Tohardi. 2007. Gambaran Anatomi Mikroskopik dan Kadar Malondialdehida pada Hati Mencit Setelah Pemberian Minyak Kelapa Sawit Bekas Menggoreng. Jurnal Kesehatan Masyarakat. Universitas Kristen Maranatha.

Ratna, Dian Anggita. 2009. Pengaruh Yoghurt terhadap Aktivitas Protease dan Gambaran Histologi Jejunum Tikus Putih ( Ratus Norvegicus) yang Terpapar Formalin. Skripsi. Universitas Brawijaya Malang.

Winarsi M.S, Dr. Hery. 2011. Antioksidan Alami dan Radikal Bebas. Yogyakarta : Kanisius.

Winarno, F.G. dan Fernandez, Ivone E. 2007. Susu dan Produk Fermentasinya. Bogor : M-Brio Press.

Wijaningsih, Wiwik. 2008. Aktivitas Antibakteri In Vitro dan Sifat Kimia Kefir Susu Kacang Hijau (Vigna radiate) oleh Pengaruh Jumlah Starter dan lama Fermentasi. Jurnal Sains. Universitas Diponegoro Semarang.

Yuniarto, Redi. 2007. Pengaruh Paparan Berulang Ikan Nila (Oreochromiss niloticus) Berformalin Secara Oral Selama Satu Bulan Terhadap Perubahan Fisiologi Mencit. Artikel Skripsi. Universitas Brawijaya Malang. 